\title{
A PRACTICAL PERSPECTIVE ON TREATY \\ INTERPRETATION: THE COURT OF JUSTICE OF THE EUROPEAN UNION AND THE WTO DISPUTE SETTLEMENT SYSTEM
}

\author{
Andreas Sennekamp * \\ Isabelle Van Damme ${ }^{\dagger}$
}

\begin{abstract}
This article offers a pragmatic account of the practice of treaty interpretation by the Court of Justice of the European Union and the dispute settlement system of the World Trade Organization. The first part of the article addresses several institutional and structural aspects of the context in which treaty interpretation is undertaken and which may have a bearing on the practice of treaty interpretation. The second part of the article identifies several constraints on that practice, such as the characteristics of the treaty texts being interpreted, limitations resulting from multilingualism, as well as particular features of the decision-making processes in the Court of Justice of the European Union and the dispute settlement system of the World Trade Organization. By contributing these institutional and practical considerations to the debate on the operation of the principles set out in Articles 31 to 33 of the Vienna Convention on the Law of Treaties, the article demonstrates that, as part of the renewed interest in the law of treaties, the study of the internal functioning and design of international courts is critical for a proper assessment of the development of the law of treaties.
\end{abstract}

\section{Introduction}

The revival of the academic discourse on treaty interpretation in international law has produced an abundance of analysis and commentary regarding treaty interpretation by international courts and tribunals. In that discourse, however, factors stemming from the institutional context within which the practice of treaty interpretation is conducted have not always been taken into account. This paper focuses on these factors examining them from the perspective of

\footnotetext{
* Counsellor, WTO Appellate Body Secretariat.

† Référendaire, Chambers of Advocate General Sharpston, Court of Justice of the European Union and Visiting Lecturer, Université Catholique de Louvain.
}

Copyright $\odot$ the Author(s).

This work is licensed under a Creative Commons Attribution-NonCommercial-NoDerivs 3.0 License. 
the interpreter, be it in the capacity of judge, Advocate General or legal officer. The paper offers a pragmatic account of the professional practice of treaty interpretation and its constraints in the context of two different fora, namely the Court of Justice of the European Union (the Court of Justice or Court) and the World Trade Organization (WTO), in particular the WTO Appellate Body.

While there are important differences in the mandate and in the institutional structure of the Court of Justice and the WTO dispute settlement system, ${ }^{1}$ both institutions have used treaty interpretation as an instrument for establishing authority in their respective contexts. Each has developed its own particular method of interpretation and ways of explaining its interpretive choices. The Court of Justice's approach is characterised by, among other features, a strong attachment to teleology and considerations of effectiveness, and relatively little formalism in explaining the interpretive choices it makes. In addition, its approach to treaty interpretation is marked by the fact that there is a wide variety of sources constituting EU law for which the Court of Justice is the ultimate interpretive authority. ${ }^{2}$ Its case-law is not marked by a rigid adherence to the Vienna Convention on the Law of Treaties (VCLT) though in many cases the process or result of its interpretation can be explained by reference to the VCLT. ${ }^{3}$

WTO panels and the Appellate Body, on the other hand, interpret a more limited variety of legal instruments. The 'covered agreements' in the sense of Article 1.1 of the Dispute Settlement Understanding of the WTO (DSU) predominantly consist of a multilateral treaty. ${ }^{4}$ Unlike the Court of Justice, WTO panels and the Appellate Body usually refer expressly to the VCLT and apply the framework set out in Articles 31 and 32 of the VCLT rather formalistically. They typically explain the different steps of their interpretive analysis in relation to the VCLT, considering the meaning of the words of the text of the relevant provision in its context and in the light of the object and purpose of the treaty.

1 See e.g. C-D Ehlermann, 'Six Years on the Bench of the World Trade Court-Some Personal Experiences as a Member of the Appellate Body of the WTO' (2002) 36 JWT 605.

2 See e.g. G Conway, The Limits of Legal Reasoning and the European Court of Justice (2012); K Lenaerts \& JA Gutiérrez-Fons, "To Say What the Law of the EU Is: Methods of Interpretation and the European Court of Justice' (EUI Working Papers AEL, 2013), <http://cadmus.eui.eu/bitstream/handle/1814/28339/AEL_2013_09_DL.pdf?sequence=1> [accessed 1 February 2014].

${ }^{3}$ For a comparison between the Court's hermeneutics and treaty interpretation in accordance with public international law, see the rewritten version of Van Gend en Loos in JHH Weiler, 'Rewriting Van Gend \& Loos: Towards a Normative Theory of ECJ Hermeneutics', in O Wiklund (ed), Judicial Discretion in European Perspective (2003) 150.

${ }^{4}$ Marrakesh Agreement Establishing the World Trade Organization, 15 April 1994, 1867 UNTS 3, Annex 2, Art 1.1 (Understanding on Rules and Procedures Governing the Settlement of Disputes). 
The WTO panels and the Appellate Body are often criticised for how, and the degree to which, they rely on text and dictionary definitions. However, one of us has previously shown that their interpretive methods are indeed more varied. ${ }^{5}$

In this paper, we focus on certain practical aspects of interpretation, and in particular on several constraints arising in the practice of interpretation in both judicial systems. We start by setting out some features of the general context in which each system operates. Thereafter we consider different types of constraint. In doing so, we seek to contribute a number of practical and institutional considerations to the debate on the principles set out in Articles 31 to 33 of the VCLT.

\section{General background}

Both the Court of Justice and WTO panels and Appellate Body are engaged in the exercise of a judicial function. Yet, both institutions exercise that function in distinct contexts and their interpretive mandate is described differently. Article 19(1) of the Treaty on European Union (TEU) defines the jurisdiction of the Court of Justice in very general terms and states that: 'It shall ensure that in the interpretation and application of the Treaties the law is observed'. In contrast to many other international agreements, including the TEU, which are silent with regard to the question of how the provisions of the treaty should be interpreted, the DSU contains a specific rule setting out how the covered agreements are to be interpreted. Article 3.2 of the DSU stipulates that the dispute settlement system of the WTO serves to 'clarify the existing provisions of [the] agreements in accordance with customary rules of interpretation of public international law'.

With these considerations in mind we address several institutional aspects of the two fora, which can have a bearing on the practice of treaty interpretation.

\subsection{Size of the institution, individual cases and case-load}

The size of each institution, its case-load and individual cases handled by them shapes the way in which the judicial function is carried out, as these factors have

\footnotetext{
5 See generally C-F Lo, 'Good Faith Use of Dictionary in the Search of Ordinary Meaning under the WTO Dispute Settlement Understanding' (2010) 1 JIDS 431; I Van Damme, 'Good Faith Use of Dictionary in the Search of Ordinary Meaning under the WTO Dispute Settlement Understanding-A Reply to Professor Chang-Fa Lo' (2011) 2 JIDS 231; C-F Lo, 'A Clearer Rule for Dictionary Use Will Not Affect Holistic Approach and Flexibility of Treaty Interpretation-A Rejoinder to Dr Isabelle Van Damme' (2012) 3 JIDS 89.
} 
a bearing on the style and form of judicial decision-making. Each institution has developed a particular style of judicial decision-making. Decisions by the Court are typically much shorter than decisions by WTO panels and the Appellate Body, and there are important differences between an average case at the Court and at the WTO in terms of content, number and length of submissions and exhibits, as well as the number of parties involved, although no perfect comparison is possible.

In addition, the case-load of the Court significantly exceeds that of the WTO dispute settlement system. In 2011, the Court of Justice completed 550 cases, whereas only 10 panel reports and 6 Appellate Body reports in original proceedings (as opposed to compliance and other types of proceedings) were issued. In 2012, in Luxembourg, 527 cases were completed while, in Geneva, 6 panel reports and 6 Appellate Body reports in original proceedings were issued. ${ }^{6}$

In order to complete these cases, the Court then had available 27 judges $^{7}$ and eight Advocates General ${ }^{8}$ each working with three to four référendaires, though typically only one référendaire will work on a given case. By contrast, three ad hoc panelists hear a case at the panel stage at the WTO, and at the Appellate Body a division composed of three out of seven permanent Appellate Body Members hears an appeal. A team of typically three to four lawyers assists a division of the Appellate Body in a case. Overall, there are currently 12 lawyers working at the Appellate Body Secretariat and 41 lawyers in the Legal Affairs Division and in the Rules Division, assisting first instance panels.

There are important variations in the size of cases adjudicated within both systems. Where possible, the Court of Justice attempts to control the length of written observations and pleadings through guidelines or by imposing strict time limits for pleadings. ${ }^{9}$ Limitations on the length of written submissions have

\footnotetext{
${ }^{6}$ Regarding the WTO, see Total Reports and Awards Circulated Each Year, <http://www.worldtradelaw.net/dsc/database/reportcount.asp > [accessed 4 February 2014]; regarding the Court of Justice, see Annual Report 2012, 1 January 2013, $10<\mathrm{http}$ ://curia.europa.eu/jcms/upload/docs/application/pdf/2013-04/192685_2012_6020_cdj_ra_2012_en_proof_01.pdf> [accessed 1 February 2014].

${ }^{7}$ As a result of Croatia's accession to the European Union, there are (as of 1 July 2013) 28 judges at both the Court of Justice and the General Court.

8 There are now nine Advocates General.

9 Court of Justice of the European Communities, Notes for the guidance of counsel in written and oral proceedings before the Court of Justice of the European Communities, February 2009, 25 <http://curia.europa.eu/jcms/upload/docs/application/pdf/2008-09/txt9_2008-09-25_17-37-52_275.pdf> [accessed 1 February 2014]; in addition, Art 58 of the Rules of Procedure of the Court of Justice, [2012] OJ L 265/1 states that
} 
also been considered at the WTO, ${ }^{10}$ although to date no such limitations have been adopted. However, as a matter of standard practice the Appellate Body imposes limitations on the length of oral statements in hearings. There is a trend, perceptible at both the Court of Justice and at the Appellate Body, towards an increase in the number of grounds of appeal in appellate proceedings. At the Appellate Body, the average number of issues raised in each appeal has increased from approximately eight issues per case in the first ten appeals during the period spanning from 1996 to early 1998 to more than 13 issues per case in the ten appeals adjudicated by the Appellate Body between the beginning of 2011 and the end of 2012. ${ }^{11}$

Finally, it is important to note that at the Court, with few exceptions, written observations filed by the parties are translated by the institution itself into at least the working language of the Court, which is French. In addition, both in Luxembourg and in Geneva the institutions provide simultaneous interpretation at the oral hearings. Both translation of documents and interpretation at the oral hearings contribute to the complexity of proceedings, particularly so at the Court, as the European Union $(E U)$ has many more official languages than the WTO.

\subsection{Jurisdiction}

Jurisdiction of the Court of Justice and the WTO dispute settlement system is both compulsory and exclusive. A condition set for acceding to the EU and the WTO is acceptance of their jurisdiction and of the requirement to submit disputes about the interpretation and application of EU law and WTO law, respectively, to those fora. The WTO dispute settlement system serves to resolve disputes between WTO Members about the interpretation and application of the covered agreements. Individuals have no standing and national courts cannot refer questions to either a panel or the Appellate Body.

The jurisdiction of the Court of Justice is much more varied, in terms of the type of proceeding, the actors involved and the subject matter of jurisdiction. Leaving aside the jurisdiction of the General Court and that of the Civil Service Tribunal (where individuals have standing subject to different conditions), in

'[w]ithout prejudice to any special provisions laid down in [the Rules of Procedure], the Court may, by decision, set the maximum length of written pleadings or observations lodged before it'.

${ }^{10}$ See: A Jara, Progress Report on Informal Consultations to Enhance Efficiency of the Panel Process, 13 March 2012, <http://www.wto.org/english/news_e/news12_e/ddg_13mar12_e.htm> [accessed 1 February 2014].

11 Appellate Body, 'Annex 1: The Workload of the Appellate Body' in Annual Report for 2013, WTO Doc WT/AB/20, 14 March 2014, 32, 35. 
general the Court can consider issues of law and fact in infringement proceedings (the comparison here being with panel proceedings though the Court acts as a court of first and last instance), or issues of law in either appellate proceedings or preliminary ruling proceedings. In terms of framing the interpretive questions to be addressed, the Court is flexible in reformulating questions in preliminary ruling proceedings in a manner that it is evidently precluded from doing in, for example, appellate or infringement proceedings.

\subsection{Institutional context}

Both the Court of Justice and the WTO dispute settlement system operate in the context of a particular legal regime, the features of which have implications for the institution's approach to treaty interpretation. One key difference between the organisations they belong to relates to the number of members -28 versus 159 , respectively-as well as their respective membership's political, economic and cultural diversity.

The Court of Justice is part of a comprehensive institutional model. The balance of powers between the EU institutions as they stand today has evolved over time, resulting in a wider scope of the jurisdiction of the Court and more ample powers of the European Parliament in the legislative process. The Court's interpretations of the Treaties (primary law) and secondary legislation (secondary law) are part of an evolving institutional environment. Decisions of the Court sometimes prompted legislative developments and initiatives for treaty amendment. At the outset, it appeared doubtful whether initial steps of European integration were aimed at establishing solely a treaty-based system, fully part of public international law, or whether the drafters of the founding Treaties intended to create a closer union and a sui generis type of legal system. In Van Gend en Loos and later in Costa $v$ Enel, the Court actively asserted that (what is now called) the EU is a separate autonomous legal order and that, provided certain conditions are met, EU law (whether or not treaty law) could create directly effective rights for individuals which they could invoke before national courts. ${ }^{12}$ Unlike WTO law (with respect to which, in the absence of a provision to that effect in the agreements themselves, it is for national law of each WTO Member to determine its effect within the domestic legal order), EU law-as ultimately interpreted by the Court of Justice-sets the terms on which it permeates into the national laws of Member States. By virtue of the doctrines of supremacy, direct

\footnotetext{
${ }^{12}$ See Case C-26/62, Van Gend en Loos v Nederlandse Administratie der Belastingen [1963] ECR 1, 12; Case C-6/64, Costa v Enel [1964] ECR 585.
} 
effect and the principle of consistent interpretation, judgments of the Court of Justice penetrate deeper and more directly into the national legal systems of the EU Member States. WTO law does not itself set the terms for its effect in the municipal law of WTO Members. While, as a matter of international law, failure to implement dispute settlement reports might entail state responsibility, it is for each WTO Member to determine the effects of these reports in its legal order.

By contrast, the WTO's institutional model does not include a parliamentary assembly, the extent of its political bodies' powers remain uncertain and it largely misses effective governance structures enabling the organisation to adapt to changing circumstances and to adopt new legal instruments. The creation of the WTO dispute settlement system was undertaken in order to judicialise dispute resolution, making it rules-based rather than controlled by politics. ${ }^{13}$ Panel and Appellate Body reports become binding on the parties after adoption by the Dispute Settlement Body $(D S B)$ which has become quasi-automatic because of the reverse-consensus rule. In addition, drawing on the text of Article 3.2 of the DSU, which stipulates that the dispute settlement system shall provide security and predictability to the multilateral trading system, the Appellate Body held in US - Stainless Steel (Mexico) that the mandate of 'clarify[ing] the existing provisions of [the] agreements' goes beyond interpretation and application of a provision in one particular case. In this decision, the Appellate Body referred to the development of a coherent and predictable body of jurisprudence clarifying Members' rights and obligations under the covered agreements. ${ }^{14}$

While the number of cases adjudicated by the WTO dispute settlement system seems low in comparison to the number of cases adjudicated by the Court, the WTO dispute settlement system has produced a rich practice of interpretation in the almost twenty years of its existence. This contrasts with the paralysis of the legislative branch of the WTO, which arguably lacks decision-making processes allowing for a gradual evolution of the legal rules. Contrary to the EU system, where the legislator can react to a decision of the Court by adopting new legislation, by changing legislation (and ultimately the Treaties) or by codifying existing case-law, WTO Members lack similar means to react quickly to a decision by a panel or by the Appellate Body. In practice, amendments to the WTO covered agreements require consensus among WTO Members. These

${ }^{13}$ See J H Jackson, "The Evolution of the World Trading System - The Legal and Institutional Context' in D Bethlehem, D McRae, R Neufeld \& I Van Damme (eds), The Oxford Handbook of International Trade Law (2009) 30, 45-53.

${ }^{14}$ Appellate Body, United States - Final Anti-Dumping Measures on Stainless Steel from Mexico, WTO Doc WT/DS344/AB/R (30 April 2008) para 161 (US - Stainless Steel (Mexico)). 
rigidities have resulted in an imbalance between the political branch and the judicial branch within the WTO.

Furthermore, the institutional architecture of the organisations to which the Court of Justice and the Appellate Body belong are different in that the Commission is involved in every case before the Court, defending the Union's interests. No similar defender of the objectives of the WTO exists in WTO dispute settlement. While the DSB establishes panels and adopts panel reports and Appellate Body reports, it is not actively involved in the disputes.

Finally, if jurisprudence is seen as a form of dialogue between the actors appearing before the court and the judges hearing a case, then the nature of this interaction and the style of this discourse might also be shaped by features of the professional communities appearing before the Court of Justice and the Appellate Body. The Court sees a variety of actors appearing before it, ranging from repeat players (such as the Commission and to a lesser extent Member States and other institutions, depending on the type of dispute) to first time players (such as counsel for parties to the main proceedings before a national court that has requested a preliminary ruling). In WTO dispute settlement, however, Members are typically represented by a delegation of their government, often assisted by legal counsel. There is typically no role for representatives of the other bodies of the WTO, of other international organisations, or of individuals in WTO dispute settlement, nor is there representation of the interest of the WTO.

\section{Constraints on the practice of interpretation}

Against the background of some of the factors shaping the exercise of the judicial function in the Court and in WTO dispute settlement, we now consider several constraints existing in the practice of interpretation in the two fora.

\subsection{Texts}

Treaty text usually provides a certain degree of specificity but is, almost inevitably, also incomplete. With regard to the legal instruments interpreted by the Court and in WTO dispute settlement, there appear to be similarities in the terms, the style and the function of certain provisions, such as exception clauses or provisions setting out the fundamental principles of non-discrimination, the basic rights of free movement, or the prohibition on quantitative restrictions. At the same time there are also significant differences. The WTO treaty text, such as the Agreement on the Application of Sanitary and Phytosanitary Measures 
or the Customs Valuation Agreement, is in many instances much more detailed than the text found in the EU Treaties, making the former more akin to different forms of secondary EU law with respect to which the Court is also the final interpretive authority. On the contrary, primary EU law tends to express broad principles using language of greater indeterminacy than many provisions in the WTO covered agreements. ${ }^{15}$ This might be one of the reasons why the Court of Justice has exercised greater discretion in interpreting the EU Treaties. Even where the language in the EU Treaties-or secondary forms of EU law-is more precise or more technical, general principles of EU law form part of the inherent context in which other, more formal, sources of EU law must be interpreted. ${ }^{16}$

While the Court routinely interprets secondary law adopted by EU institutions, these institutions may themselves adopt legislation (or amend the Treaties) so as to either codify or override an interpretation articulated in a decision of the Court. In the context of the WTO, the legislative arm of the institution is much more constrained, on the one hand, because instruments akin to secondary law are not properly developed, and, on the other hand, because the process for amending instruments of primary law is almost on the verge of paralysis. This further enhances the rigidity of the WTO Agreements and weighs in favour of a text-based interpretation by panels and the Appellate Body.

Yet, whatever the particular features of the law being interpreted, and despite different reasons explaining the interpretive choices used in the two fora, there cannot be any doubt that those who interpret start by considering the text of the treaty, directive, regulation or other documented form of law. The text expresses the intent of the drafters-or at least a degree of consensus-by all Members or a group thereof whose majority is considered to be sufficient for accepting that text as law. The allocation of interpretive authority to a third party generates a mandate for that party to produce an interpretation that replaces the individual, and therefore possibly more subjective, positions taken by those facing an interpretive problem in a dispute.

The Appellate Body's approach to treaty interpretation is sometimes classed as belonging to the 'strict constructionist school that interprets texts literally and narrowly. ${ }^{\prime}$ Moreover, the Appellate Body's reasoning has been described

${ }^{15}$ See also Lenaerts \& Gutiérrez-Fons, above n 2, 15.

${ }^{16}$ See, generally, K Lenaerts \& J A Gutiérrez-Fons, 'The Constitutional Allocation of Powers and General Principles of EU Law' (2010) 47 CMLR 1629.

${ }^{17}$ G Abi-Saab, 'The Appellate Body and Treaty Interpretation' in G Sacerdoti, A Yanovich \& J Bohanes (eds), The WTO at Ten - The Contribution of the Dispute Settlement System (2006) 453, 461; see also J Pauwelyn \& M Elsig, 'The Politics of Treaty Interpretation: Variations and Explanations 
as privileging close contact with the words of the treaty over reasoning based on general considerations of object and purpose of the treaty. ${ }^{18}$ It is widely known and visible that the Appellate Body often uses dictionary definitions as a starting point for its interpretation of treaty text. In addition, the Appellate Body typically articulates the interpretive methods it applies clearly, even to the point of a 'laborious and mechanistic handling ${ }^{19}$ of the principles codified in Articles 31 and 32 of the VCLT.

However, this emphasis on the text of the treaty does not necessarily suggest that the Appellate Body does not attribute sufficient weight to the other criteria of interpretation, such as context or object and purpose. As one of us has described elsewhere, ${ }^{20}$ even the Appellate Body's use of dictionaries is not an entirely neutral exercise because, in choosing between different dictionaries and dictionary definitions, the interpreter inevitably makes a choice and starts to contextualise. The Appellate Body typically considers the ordinary meaning of the words of the treaty along with the context and the object and purpose of the treaty. On occasion, the Appellate Body has also considered subsequent agreements, ${ }^{21}$ subsequent practice, ${ }^{22}$ as well as other relevant rules of international law pursuant to Article 31(3)(c) of the VCLT, ${ }^{23}$ and it has taken recourse to supplementary means of interpretation in the sense of Article 32 of the VCLT. In using context, the object and purpose, and possibly other considerations such as the principle of effectiveness, the Appellate Body often explains its interpretive choices by reference to the different provisions and individual sub-paragraphs of the VCLT. When applying the principle of effectiveness, the Appellate Body focuses especially on the effectiveness of an individual agreement as a whole as well as the inter-effectiveness of different agreements and it maintains a strong focus on the text of the treaty. The Appellate Body thus

Across International Tribunals', in J L Dunoff \& MA Pollack (eds), Interdisciplinary Perspectives on International Law and International Relations - The State of the Art (2012) 445, 452.

${ }^{18}$ Abi-Saab, above n 17, 461; Ehlermann, above n 1, 615-16.

${ }^{19}$ Abi-Saab, above n 17, 458.

${ }^{20}$ See generally I Van Damme, Treaty Interpretation by the WTO Appellate Body (2009).

${ }^{21}$ See e.g. Appellate Body, United States - Measures Concerning the Importation, Marketing and Sale of Tuna and Tuna Products, WTO Doc WT/DS381/AB/R (16 May 2012) paras 371-7 (US - Tuna II (Mexico)).

${ }^{22}$ See e.g. Appellate Body, European Communities - Customs Classification of Frozen Boneless Chicken Cuts, WTO Doc WT/DS269/AB/R, WT/DS286/AB/R (12 September 2005) paras 251-76 (EC Chicken Cuts).

${ }^{23}$ See e.g. Appellate Body, United States - Definitive Anti-Dumping and Countervailing Duties on Certain Products from China, WTO Doc WT/DS379/AB/R (11 March 2011) paras 307-16 (US Anti-Dumping and Countervailing Duties (China)). 
employs the principle of effectiveness in order to give meaning and effect to all components of the agreements it applies and interprets.

In the Court of Justice, it is less common to see references to dictionary definitions as a starting point for the interpretive exercise. Indeed, given the number of official languages at the Court, it would be quite impracticable for the Court to consult dictionary definitions for different words used in different language versions of the treaty and explain the reasons for adopting one and not another. Ultimately, the main reason why the Court gives less prominence to dictionary definitions may simply be a matter of judicial style. However, the fact that decisions of the Court contain fewer references to dictionaries does not necessarily mean that dictionaries are not used by the Court or that positions on the ordinary meaning of a word or provision are reached in isolation of considerations that panels and the Appellate Body expressly include in the formal explanation of their interpretive process. With regard to the principle of effectiveness, it is worth noting that the focus of the Court is on the effectiveness of the EU as an organisation and the separate autonomous legal order that it forms. Indeed, the Court's creation of general principles of EU law must be seen as part of that concern. ${ }^{24}$

In both contexts, a focus on one out of several means of interpretation might also be a function of the nature of the obligation or right described in the text being interpreted. In this vein, considerations of object and purpose might be particularly relevant with respect to the interpretation of broadly circumscribed principles, such as those in the area of fundamental rights. Many of the obligations contained in the WTO Agreements, however, are not of that type. Rather, they contain a number of more or less narrowly circumscribed rights and obligations; broader considerations of object and purpose may not always be very helpful for interpreting such provisions. On the other hand, these obligations are complemented with exceptions, such as the general exception of Article XX of the GATT 1994. ${ }^{25}$ Some of the exceptions make reference to broader concepts, which might be structurally similar to those in the area of fundamental rights and, consequently, considerations of object and purpose may feature more prominently in the interpretation of these provisions.

Thus, it would appear that if, in practice, interpretation is best characterised as the exercise of moving from one concentric circle to another, ${ }^{26}$ the circles as

\footnotetext{
${ }^{24}$ See Lenaerts \& Gutiérrez-Fons, above n 16, 1632.

${ }^{25}$ Marrakesh Agreement Establishing the World Trade Organization, 15 April 1994, 1867 UNTS 3, Annex 1A, Art 20 (General Agreement on Tariffs and Trade 1994) (GATT 1994).

${ }^{26}$ M Huber, 'Commentaire de l'interprétation des traités' (1952) 44 Annuaire de l'Institut de droit
} 
such are not fundamentally different in the interpretive practice of the Court of Justice and the WTO. Yet, the considerations made when moving, for example, from the ordinary meaning, to the immediate and broader context, and then to the object and purpose and other elements of interpretation might be different. The same would appear to apply to the proximity of the different circles.

\subsection{Multilingualism}

While the constraints resulting from multilingualism are undoubtedly more visible in Luxembourg, both judicial systems interpret texts which are authentic in different languages. The WTO agreements are authentic in English, French and Spanish. ${ }^{27}$ The different formal sources of EU law are authentic in the 24 official EU languages. ${ }^{28}$

It is not unlikely that a single person (whether it be a judge, an Advocate General or a legal officer) masters the three official languages of the WTO, but it is quite impossible that he or she is proficient in all EU languages. This results undoubtedly in matters getting lost in translation and renders the application of the rule in Article 33 of the VCLT often somewhat impracticable at the Court. The constraints of performing the judicial function in a multilingual environment are most visible in the Court of Justice. ${ }^{29}$ Taking the example of the preliminary ruling procedure, a reference might arrive in any of the 24 official languages depending on which national court refers the matter to the Court. That reference, and at least the question(s) referred, typically will be translated into all other official languages and the various parties authorised to intervene (including the different Member States) might file written observations in different languages. All of these documents are then translated into French which is the internal working language of the Court. Hearings will then be organised with simultaneous interpretation. An Advocate General might write an opinion in English and the reporting judge may prepare a draft judgment in French which is then the basis, in principle, for the délibéré in French with other judges in a chamber of three, five or fifteen judges, none of whom might be native French speakers. A given provision will be read in French and possibly

int'l 198, 200; M Koskenniemi, 'Fragmentation of International law: difficulties arising from the diversification and expansion of international law: Report of the Study Group of the International Law Commission', UN Doc A/CN.4/L.682, 13 April 2006, paras 463-4 .

${ }^{27}$ Marrakesh Agreement Establishing the World Trade Organization, 15 April 1994, 1867 UNTS 3, Art 16 (Marrakesh Agreement).

${ }^{28}$ Consolidated Version of the Treaty on European Union, [2012] OJ C 326/13, Art 55(1) (TEU).

${ }^{29}$ See also Lenaerts and Gutiérrez-Fons, above n 2, 8-13. 
in the other languages in which the judge(s), Advocate General and legal officer(s) working on the case are proficient. At the same time, the text of a regulation or directive might itself not be perfectly uniform in the different language versions in which it is available. Indeed, there might be some differences in language versions of the Treaties. ${ }^{30}$ The resulting judgment or opinion will be translated by a separate team of lawyer-linguists into different languages and it is simply impossible, taking into account the limited resources available, for the drafters of the original document to verify each translation. If treaty interpretation is in essence the process of finding meaning of an authoritative text agreed as having the status of law in different language versions, it thus appears evident that by definition that process will be imperfect in a context such as that of the Court of Justice.

By comparison, multilingualism in the WTO presents fewer challenges. In the overwhelming majority of disputes, the parties have chosen to make their submissions in English. On occasion, parties have filed submissions in Spanish or French. At the Appellate Body, however, this has so far not led to a change in the language of the proceeding in those disputes. Up to today, all Appellate Body reports have been drafted in English and have subsequently been translated into Spanish and French. Nonetheless, the Spanish and the French texts of the covered agreements are sometimes referred to in arguments by the parties in a dispute as well as by the Appellate Body in its reasoning. ${ }^{31}$

\subsection{Preparing a judgment or report}

The internal processes for preparing the final judgment or report in a case differ greatly in the Court of Justice and the WTO dispute settlement system. This has an impact on styles of explaining interpretive reasoning. This is partly due to the type of jurisdiction being exercised, the multilingual regime, the case-load, the internal organisational structure in the respective systems and the time available to deliver a judgment or report.

In the Court of Justice, internal preparations of a case, in terms of substantive treatment, typically start only after the written procedure is completed and, depending on the language of proceedings, when translations of all written

\footnotetext{
${ }^{30}$ See e.g. Case C-219/95 P, Ferriere Nord SpA v Commission [1997] ECR I-4411, paras 12-14.

${ }^{31}$ See e.g. the relevance of the French and the Spanish versions of the GATT 1994 Art III:8(a) for the Appellate Body's interpretation of the term 'governmental purposes' in Appellate Body, Canada - Renewable Energy \& Canada - Feed-in Tariff Program, WTO Doc WT/DS412/AB/R \& WT/DS426/AB/R (6 May 2013) para 5.67.
} 
observations are available. In that context, it must be emphasised that the written procedure is strictly separated from the oral procedure. Typically, it is not possible to begin preparatory work at an earlier stage because: (i) a full comprehension of the file is not possible until all translations are available; (ii) there are competing demands in other pending cases, taking into account that each member of the Court has a chamber of three or four lawyers, with typically only one lawyer working on a given case; (iii) depending on the type of jurisdiction, there is a possibility of anticipating new issues. After translations become available, the burden is on the so-called reporting judge to prepare a preliminary report on the case, describing the applicable law, the issues at stake and the arguments made as well as assessing the complexity of the case and setting out suggestions on how the Court should treat the case procedurally (for example, whether a hearing is required, an opinion of an Advocate General is needed, or whether the case should be allocated to a chamber of three, five or fifteen judges). That report is then first considered by the Advocate General, who is expected to accept but not approve the report-a subtle but nonetheless important distinction because the ownership over the report remains with the reporting judge. Ultimately, the report is considered by all members of the Court at their weekly meeting. Following that meeting, the jurisdiction of the Court is exercised by the specific chamber to which the case is allocated. This means that, unlike the WTO Appellate Body, there is in principle no exchange of views with the full court, even on matters of fundamental importance referred to the Grand Chamber. In exceptional cases, the full Court will consider a case. ${ }^{32}$ Following that stage, a hearing might be organised and an opinion of the Advocate General might be delivered before the reporting judge returns to a full study of the case and prepares a draft judgment ready to be deliberated. In the Court there are fewer possibilities of-at a preliminary stage, possibly even before the Court's jurisdiction is seized-studying the case in a horizontal level and having available a general reflection document against the background of which to consider a particular case. At best, the Court might ask the department 'Research and Documentation' to collect the relevant case law in a particular area or Member States' practice in a certain area.

At the Appellate Body, work on an appeal typically begins once a panel report has been circulated, regardless of whether that panel report will ultimately be

\footnotetext{
${ }^{32}$ See e.g. Case C-370/12, Thomas Pringle v Government of Ireland [2012] 2 CMLR 2; Opinion O-2/13, Request for an opinion submitted by the European Commission pursuant to Article 218 (11) TFEU [2013] OJ C 260.
} 
appealed or not. This is so because the 90-day deadline for the completion of an appeal proceeding and translation of the Appellate Body report into the three official languages of the WTO could not be met if preparation started only once a notice of appeal had been filed. The case is assigned to a team of lawyers of the Appellate Body Secretariat. That team will study the case, compile relevant case law and academic writing and assist the Appellate Body division hearing the appeal throughout the proceeding. The appeal proceeding is officially initiated with the filing of a notice of appeal with the WTO Dispute Settlement Body and the Appellate Body and the filing of a written appellant's submission on the same day. At that point, a division of three Appellate Body Members will be constituted to hear the case. According to Rule 6(2) of the Working Procedures for Appellate Review, the Members constituting a division are selected on the basis of rotation while taking into account the principles of random selection, unpredictability and the opportunity for all Members to serve regardless of their origin. Each division has a presiding Member, elected by the Members of that division. While it is for the division to decide all issues under appeal in a particular case, the division will hold an exchange of views with all Appellate Body Members not on the division in the case, in order to ensure consistency and coherence in the case law and to draw on the expertise of all Appellate Body Members in deciding the case. A division will make every effort to take a decision by consensus. However, if consensus cannot be reached, the matter may be decided by majority vote. ${ }^{33}$

\subsection{Internal actors}

To some extent, differences in the approach to interpretation in the Court and in the Appellate Body might be a function of the background of the individual adjudicators or legal officers serving on the respective adjudicative bodies. At the Court of Justice, the internal actors are all lawyers and nationals of the Member States. Their backgrounds vary widely but most of them have studied law and then practised in some form or another in a context wherein EU law is internalised in national law. The Court does not employ economists; an earlier experiment of employing an economist at the General Court was short-lived. Expertise in a particular area of EU law might be valuable but ultimately, taking into account the breath of EU law and width of the Court's jurisdiction, the

\footnotetext{
${ }^{33}$ Working Procedures for Appellate Review, WTO Doc WT/AB/WP/6, 16 August 2010, Rule 3(2); see also, P Van den Bossche \& W Zdouc, The Law and Policy of the World Trade Organization $\left(3^{\text {rd }}\right.$ edn, 2013) 234.
} 
chances of working on cases involving matters not studied or otherwise known before are high.

With regard to WTO dispute settlement, Articles 8 and 17.3 of the DSU, respectively, set out the criteria of eligibility for panelists and Members of the Appellate Body. These provisions do not require individuals serving on panels or on the Appellate Body to be lawyers. In practice, however, the great majority of individuals having served and currently serving as Appellate Body Members have been or are lawyers. At the panel stage, appointment of individuals who are not lawyers is a more frequent phenomenon. However, all members of the professional staff at the Appellate Body Secretariat are lawyers and so is the vast majority of staff assisting first instance panels. However, in recent years, the involvement of economists, usually from the Economic Research and Statistics Division of the WTO, has become more frequent particularly in trade remedy cases.

\subsection{Internal decision-making: or exchange of views}

Both judicial systems involve, in most cases, a consensus among at least three Members or judges. At the Appellate Body, decision-making involves a consensus of the three Members of a division hearing an appeal. At the Court, the required majority will depend on the size of the chamber hearing the case.

In the WTO dispute settlement system, dissenting opinions-often on individual issues-are not prohibited. Article 14.3 of the DSU stipulates that opinions expressed in a panel report by individual panelists shall be anonymous. Similarly, pursuant to Article 17.11 of the DSU, opinions expressed in an Appellate Body Report by individual Appellate Body Members shall be anonymous. Thus, separate opinions are permitted at both the panel and appellate stage. The Working Procedures for Appellate Review, however, also stipulate that an Appellate Body division shall make 'every effort' to decide by consensus. In practice, there have been very few Appellate Body Reports containing separate, dissenting, or concurring opinions, and they typically concern rather specific and narrowly circumscribed questions. Conversely, separate opinions are prohibited in the Court of Justice. ${ }^{34}$

\footnotetext{
${ }^{34}$ Members of the Court of Justice do, however, appear to have a wider freedom to comment in an extrajudicial context on the case law of the Court and sometimes even on matters not yet resolved by the Court. Illustrations are discussed in A Vauchez, 'The transnational politics of judicialization. Van Gend en Loos and the making of EU polity' (2010) 16 Eur LJ 1.
} 
In both systems, in principle, it is impossible to discern from the decision the majority in the relevant chamber or division, discussions of which are strictly confidential. ${ }^{35}$ The need to make the interpretive reasoning acceptable to the majority without necessarily isolating the minority might render that reasoning more nuanced and balanced, or perhaps, to the contrary, it might lead to reasoning becoming less stringent or less clearly articulated in an attempt to accommodate the concerns of the minority. At the same time, in a chamber or in a division of three, where two judges or Members hold different views, the third judge or Member will be the decisive voice, and might thereby have a considerable impact on the decision and its form.

Interpreting texts and deciding cases in a setting involving fewer than the total members of the Court or the Appellate Body unavoidably increases risks of incoherence in the case law. Tensions between interpretive arguments can arise in different ways: from the co-existence of a final judgment or report with dissenting opinions, or from the case law itself.

In order to achieve greater coherence, the Working Procedures for Appellate Review provide that the Appellate Body division deciding a particular dispute shall exchange views with the four Appellate Body Members who are not on the division in the dispute. This takes place soon after the oral hearing and before the drafting of the Appellate Body report in the case begins. This step in the proceedings allows identifying potential disagreements at an early stage. While the decision is ultimately taken and reasoned by the division and consensus with Appellate Body Members not on that division is not necessary, the exchange of views allows the division to take potential disagreements into account. A division might choose to reason a decision in a less controversial way, if possible, in order to accommodate concerns or views of non-division Members. ${ }^{36}$

A similar exchange of views does not exist in the Court. Thus, for example, one chamber of five judges might sequentially or concurrently consider an interpretive question that is similar to that before another chamber in which five other judges sit. Allocations of cases to reporting judges and Advocates General as well as the possibilities under the Rules of Procedure for joining cases or offering them parallel treatment do not entirely prevent such parallel track situations from occurring in practice. At the same time, the number of cases before the Court of Justice and its organisational structure of chambers and different sizes of chambers permit identifying inconsistencies and uncertainties in its case law

\footnotetext{
${ }^{35}$ For the Appellate Body, see DSU Art 17.10.

${ }^{36}$ On the practice of the exchange of views see Ehlermann, above n 1, 612 .
} 
relatively quickly because similar questions of interpretation are often recurring, even if presented in a slightly different factual context. Ultimately, the Grand Chamber should and will intervene if a similar question is at issue in subsequent proceedings.

In the WTO, no mechanism similar to that of the Grand Chamber exists. In addition, there are fewer cases and therefore there are less frequent opportunities to revisit, refine or review interpretive decisions. Nor do the WTO dispute settlement procedures foresee that reports might be preceded by a publicly available opinion of the Advocate General. While the style and form of such opinions in the Court of Justice might vary widely, they nonetheless often set out a wider interpretive analysis than that found in the judgments. Advocates General might be less pre-occupied by the consideration of deciding a case on the narrowest grounds available and, due to their very function, have more freedom in considering an interpretive question at a more abstract level. It is not uncommon that, in cases where the Advocate General's opinion is followed, the Court's explanation of its interpretation is but a shorter version of that found in the opinion or that a full comprehension of the Court's reasoning involves reading the opinion together with the Court's judgment. ${ }^{37}$ Or, the Court might disagree or not yet be willing to agree with the Advocate General's interpretation (a subtle but nonetheless visible distinction); in such cases, it is not uncommon that the interpretive analysis might be quite short.

\section{Conclusion}

The Court of Justice and the WTO dispute settlement system have developed different ways of articulating their methods of interpretation. This is not necessarily a reflection of different positions on the content of the principles of treaty interpretation as codified in the VCLT. Interpreters in both institutions operate in different environments and face several practical constraints in interpreting treaties. These must be taken into consideration in assessing the methods of interpretation that have evolved in the two systems. In this paper we have addressed some of these constraints. This review demonstrates that, as part of the renewed interest in the state of the law of treaties, the study of the internal functioning and design of international courts is critical in properly assessing

\footnotetext{
${ }^{37}$ See e.g. Case C-440/12, Metropol Spielstätten Unternehmergesellschaft v Finanzamt HamburgBergedorf [2013] ECR I-0000, para 40.
} 
what jurisprudential developments serve as evidence of the development of the law of treaties. 